\title{
Communication Regulation Ability Depending on Honorific Type in Children with High-Functioning Autism
}

\author{
Myung-hee Lee ${ }^{\mathrm{a}}$, Seungha Song ${ }^{\mathrm{b}}$, Young Tae Kim ${ }^{\mathrm{a}}$ \\ a'Department of Communication Disorders, Ewha Womans University, Seoul, Korea \\ ${ }^{b}$ SAM Child Language Development Center, Seoul, Korea
}

Correspondence: Young Tae Kim, PhD Department of Communication Disorders, Ewha Womans University, 52 Ewhayeodae-gil, Seodaemun-gu, Seoul 03760, Korea

Tel: $+82-2-3277-2120$

Fax: +82-2-3277-2122

E-mail: youngtae@ewha.ac.kr

Received: April 5, 2020

Revised: May 1, 2020

Accepted: May 1, 2020

This study was supported by the Ministry of Education of the Republic of Korean and the National Research Foundation of Korea (No. NRF2018S1A3A2075274).

\begin{abstract}
Objectives: Children with high functioning autism spectrum disorders (HF-ASD) have relatively intact form of language, however they have deficits in using language. The Korean language has a rich honorific system; which involves not only the grammatical domain, but also the pragmatic one. The purpose of this study was to investigate the communication regulation ability depending on honorific types (non-honorifics vs. honorifics, vocabulary vs. grammatical morphemes) between children with HF-ASD and typically developing children (TD). Methods: Twelve 5- to 9-year-old children with HF-ASD and twelve TD children participated in this study. Children were asked to judge if presented conversations which had honorifics were correct or not, and then to modify them if they are incorrect. The task consisted of 23 items which had conversations with honorifics and non-honorifics. Results: The HF-ASD group showed lower performance in recognition of honorifics compared to the TD group. TD children had higher scores in non-honorifics than in honorifics, but HF-ASD children showed the opposite result. The HF-ASD group had lower scores in vocabulary and grammatical morpheme regulation. Conclusion: Children with HF-ASD have difficulty in communication regulation skills depending on honorific types. They seem to have difficulty in recognizing honorifics and modifying the honorific errors in conversations. Therefore; it is necessary to help them to recognize the situations in which honorifics are needed before teaching honorific systems.
\end{abstract}

Keywords: Communication regulation, Honorifics, Pragmatic language, High-functioning autism spectrum disorders (HF-ASD)
존대법은 본질적으로 사람과 사람의 관계, 말이 쓰이는 언어사 회를 적극적으로 반영하며, 가장 사회적인 요소로 사람들과 관계 를 맺는데 중요한 언어로 작용한다(Li, 2014). 그 중요성이 말해주 듯이 존대법은 최근까지도 많은 연구가 이루어지고 있다. 존대법 사용에 영향을 미치는 요인들로는 여러 사회적 요인, 즉 나이, 사회 적 지위, 성별, 친밀성, 친인척 관계, 언어적 행위가 이루어지는 장면 등이 있다. 그리고 실제 존대법 사용 시에는 화자와 청자의 관계가 친밀할수록 앞서 언급한 요인들은 영향력이 약해져 존대법을 사용 하지 않는 상황이 존재하기도 한다(Han, 2002). 존대법이 발달하지 않은 것으로 알려진 영어에서도 '존대법(honorific systems') 은 공식
적인 상황에서 타인을 부르는 호칭(Mr./Mrs.) 등으로 실현되며, 언 어 사용자의 공손함(politeness)을 인식하는 기준이 된다. 한편 아 시아권 나라 중에서도 일본의 경우에는 존대법이 발달하였고, 공 손함은 사회적인 의미로 관계나 개인의 특징에 따라 실현된다 (Okamoto, 1999). 이처럼 존대법 사용은 단순한 어법을 넘어 사회의사소통 맥락에 따라 다양할 수 있고, 특정 사회의 문화를 반영하 며, 자신의 말을 대화 상대자에 따라 다르게 사용한다는 점에서 의 사소통 조율능력의 한 부분으로서 설명할 수 있다.

의사소통 조율능력이란 화용언어(pragmatic language) 능력의 하나로, 의사소통과 관련된 청자, 상황, 문맥 등에 맞게 자신의 말을 
적절히 조절하는 능력을 말한다. 예를 들어 한 화자가 청자와 대화 하는 상황에서 청자의 관심사를 고려하여 이전의 대화 주제와 연 결되도록자신의 말을 적절히 조절할 수 있는 능력은 일상생활에서 일어나는 대화에서 다른 사람과 의사소통하고 상호작용하며 살아 가는데 중요하다고 할 수 있다(Choi \& Lee, 2015). 성공적인 대화를 이끄는 의사소통 조율능력을 갖추기 위해서는 언어 사용역 변이 (register variation)를 이해하는 것과 전제능력(presupposition)을 필요로 한다(Paul, 2007; Oh, Lee, \& Kim, 2012). 먼저 언어 사용역 변이(register variation)는 상황맥락에 맞게 자신의 언어 형태를 유 동적으로 사용하는 것을 말한다. 여기에는 예의 바른 언어 사용, 대 화 상대자의 연령과 나이를 고려하여 말하는 것, 대화 상대자와 주 제, 상황에 맞는 어휘를 선택하는 것, 또래관계에서 나이에 맞는 언 어를 사용하는 것 등이 이에 해당한다. 다음으로 전제능력(presupposition)은 자신의 의도를 전달하기 위해 청자의 배경지식과 요구 가 다르다는 것을 이해하고, 청자가 이해하는 바를 추론하여 정보 의 양을 조절하는 능력과 마음읽기(mind-reading)능력 등이 해당 된다(Paul, 2007). 특히 대화 상황에서 화자가 말하고자 하는 정보 의 전제가 되는 사건을 화자와 청자가 함께 공유하고 있다면, 화자 는 후속 발화에서 선행정보를 제공하지 않고 새로운 정보만을 포 함한다(Kim, 1991). 이처럼 대화 상황에 필요한 전제능력과 언어 사용역 변이는 자연스러운 대화 상황에서 화자가 제한된 정보, 불 분명한 지시사항, 우연한 언급 등을 제공할 때, 청자가 자신의 의사 소통 조율능력을 발휘하는데 중요한 요소가 되며, 대화능력을 평 가하는 지표로 사용될 수 있다(Simmons, Paul, \& Volkmar, 2014).

자폐범주성장애 아동의 경우, 언어 이전기의 의사소통 행동의 비율과 의사소통 기능이 저하되면서, 사회적 의사소통의 사용과 공동주의하기 능력의 결함을 보인다(Paul, 2007; Mundy \& Stella, 2000; Wetherby, Prizant, \& Hutchinson, 1998). 대략 60\%의 자폐 범주성장애 아동들이 6세경까지 구어를 습득하지만, 의사소통 능 력의 결함은 여전히 나타나며, 이는 학령기까지 지속이 된다고 한 다(Paul, 2007). 한편 자폐범주성장애 아동 중에서도 형식적인 언 어능력이 일반아동과 유사하게 발달하는 아동을 고기능자폐(highfunctioning autism)라고 하는데, Rapin과 Allen (1983)에 따르면, 고기능자폐 아동은 조음 정확도나 음운적 오류와 같은 점은 극히 드물게 나타나지만, 의미영역이나 화용영역에서의 어려움을 주로 보인다.

Simmons 등(2014)의 연구에서 고기능자폐 아동과 일반 아동 간 에는 대화능력에 차이가 있었으며, 고기능자폐 아동들은 주로 주 제유지, 대화수정, 전제능력, 의사소통 기능에서 일반 아동에 비해 오반응 비율이 높은 것으로 나타났다. 이와 마찬가지로 Klin과
Volkmar (2000)의 연구에서도 고기능자폐 아동들의 대화와 담화 사용에서의 언어사용 결함을 보고하였다. 특히 고기능자폐 아동 들은 타인의 정보상태에 대한 추론이나 주제의 공유에 어려움을 보이고, 일반 청소년과 비교하여 말실수의 비율이 높았다고 한다

(Chuba, Paul, Miles, Klin, \& Volkmar, 2003; Lee, Kim \& Lee, 2007).

한편 언어처리능력과 관련해서 고기능자폐 아동들은 과제의 복 잡성이 증가될수록 평균보다 낮은 수행력을 나타낸다고 하였다 (Boucher, 2011). 또한 의미처리능력에 관한 Dunn, Gomes 그리고 Sebastian (1996)의 연구에 의하면, 고기능자폐 아동은 범주적 단 서가 있는 단어 유창성 검사(Category-cued word fluency test)에서 언어능력이 일치하는 단순언어장애 집단, 일반 아동 집단과 비교하 여 상당히 낮은 수행력을 보였다. Kelley, Paul, Fein 그리고 Naigles (2006)의 연구에서도 자폐성장애 아동들의 통사 구문적 산출능력 은 비교적 잘 보존되었지만, 어휘 의미적 영역에서는 손상을 보인다 고 하였다.

Volden, Magill-Evans, Goulden 그리고 Clarke (2007)은 학령기 고기능자폐 아동을 대상으로 낮선 성인, 또래, 아기, 그리고 외국인 에게 식당 가는 방법을 설명하는 과제를 통해 언어 사용역 변이 능 력을 알아보았다. 그 결과, 고기능자폐 아동은 비언어성 인지와 언 어능력을 일치시킨 통제집단에 비해 화자에 따른 조율 표현을 적절 히 산출하지 못하였고, 단순한 구조의 표현을 여러 화자에 걸쳐 유 사하게 보였다고 한다. Volden과 Sorenson (2009)은 고기능자폐 아 동과 비언어성 인지 및 언어능력을 일치시킨 일반 또래 집단과의 비 교 연구에서 공손함의 요소를 포함시켜 대화 상대자에 따른 존대 표현이 가능한지를 살펴보았다. 연구자들은 직접 표현 과제와 대화 상황의 적절성을 판단하는 과제를 실시하였는데, 그 결과, 고기능 자폐 아동은 판단 과제에서는 또래와 차이를 보이지 않았지만, 표 현 과제에서는 유의하게 낮은 수행을 나타냈다. 존대법 실현에 있어 언어에 따른 차이가 존재하지만, 영어권 아동을 대상으로 한 연구 에 따르면, 고기능자폐 아동은 존대법에 대한 지식을 보유하고 있 어도 실제 대화 상황에서는 대화 상대자에 따른 적절한 존대 표현 에 어려움을 보인다는 것을 알수 있다.

국내에서도 고기능자폐 아동들의 의사소통 및 화용론적 특성 을 연구하기 위한 많은 시도들이 이루어져 왔다. 먼저 전제능력을 연구한 Lee 등(2007)에 따르면, 고기능자폐 아동 집단은 일반 아동 과 비교하여 전재하는 능력의 기초가 되는 '새로운 정보' 낱말 처리 에서 어려움을 보였다고 하였다. 이는 새로운 정보를 처리하기 위해 요구되는 인지적 처리 과정이 새로운 정보들이 갖고 있는 전제능력 들을 포함하여 처리하여야 하는 부담 때문이라고 하였다. Choi, $\mathrm{Oh}$ 그리고 Lee (2015)의 연구에서는 학령기 아동언어검사(LSSC) 
를 학령기 고기능 자폐아동과 생활연령을 일치시킨 일반아동에게 실시하여 그 결과를 분석하였는데, 그 결과 LSSC 전체 점수에서는 집단 간 유의한 차이가 없었지만, 수용언어 영역에서 유의한 차이 가 있었고, 문법 영역에서도 유의한 차이가 있었다고 하였다. 문법 영역 중에서도 구문이해, 문법오류판단, 문장 따라 말하기에서 유 의한차이가 나타났다고 하였다.

이처럼 국내외에서 고기능자폐 아동들의 대화 및 사회적 상호작 용능력을 평가하기 위한 많은 연구가 되었지만, 국내에서 특정 대상 에 따라 말의 형태를 조율할 수 있는 능력에 관한 연구는 이루어 지 지 않았다. 2015년 개정된 교육과정에 의하면, 존대법의 교육은 5세 교육과정에서부터 나타난다. 5 세의 듣기, 말하기, 읽기, 쓰기 영역에 는 '때와 장소, 대상에 알맞게 말한다, '바르고 고운 말을 사용한다' 는 목표가 나와있으며, 유치원에서는 이를 목표로 원 내에서 존대 법 사용을 지도하고 있다(Ministry of Education, 2015a). 또한 초등 국어 교육과정의 3-4학년 문법 영역 성취기준에는 '낱말과 문장을 사용하는 능력'과 '한글을 소중히 여기고, 언어 예절을 지키며, 의 사 소통하는 능력'을 갖추는데 중점을 두었다. 또한 '낱말, 문장 및 높임법에 대한 이해를 통해 기초적인 국어 사용 능력을 기르는 데 주안점을 둔다'고 명시되어 있다(Ministry of Education, 2015b).

만 $3,4,5$ 세 유아의 주체, 객체, 상대 존대법 습득에 관한 Park과 $\operatorname{Kim}$ (2010)의 연구에 따르면 특히 만 5 세 아동들의 경우 상대 존대 법인 '-시-'표현과 '-요'표현의 경우 75\%-95\%의 습득률을 보였으며, 만 3,4세 유아와 비교했을 때, 만 5세경에 이르러 그 습득률이 급속 히 증가하는 것으로 나타났다. 초등학교 $3,4,5,6$ 학년의 존대법 사 용 실태를 조사한 연구에서는 참여 아동에게서 주체 존대법, 객체 존대법, 상대 존대법의 사용 능력이 관찰되며, 특히 '-시-' 표현과 '-께, -께서' 그리고 '진지, 말씀, 생신 등' 일상생활과 교과서의 문어 체에서 비교적 자주 접하는 존대 어휘들을 초등학교 3 학년 아이들 부터 평균 $60 \%$ 이상 습득 및 사용하고 있는 것으로 나타났다(Kim, 2005; Lee, 2004; Won, 2003). 이와 같이 아동들은 만 5세부터 존대 법을 습득하기 시작하여 학령기에 접어들어 좀 더 자세한 존대법 의 어휘와 문법 형태소를 습득하여 다양한 대화 상대자들에게 사 용할 수 있는 것으로 보인다.

이처럼 우리말에서는 존대법의 습득이 언어 발달에서 중요하고, 이는 특히 사회적 의사소통 상황에서 더욱 유의하지만, 자폐범주 성장애 아동을 대상으로 한 존대법의 습득 및 표현에 관한 연구는 찾아보기 어려웠다. 따라서 본 연구에서는 고기능자폐 아동의 존 대법 사용에서 존대 및 하대에 따른 차이와 어휘 및 문법형태소를 활용하는 것에 따라 의사소통 조율능력이 어떠한지를 살펴보고, 그 오류 유형을 분석하였다.

\section{연구방법}

\section{연구 참여자}

서울 및 경기 지역에 거주하는 만 5 세에서 9 세의 고기능자폐 아 동 12 명과 생활연령을 일치시킨 일반 아동 12 명이 연구에 참여하였 다. 존대어 습득에 관한 선행연구에 의하면, 5 세경에 존대어 습득 률이 급격하게 증가하고(Park \& Kim, 2010), 초등 3학년에 접어드 는 만 9 세 아동의 경우, 존대법에 대한 의식을 조사한 결과 $88.4 \%$ 의 아이들이 존대법에 대한 개념을 잘 알고 있다(Lee, 2004)는 점을 고 려하여 그 연령범위를 만 5 세부터 9 세로 선정하였다.

고기능자폐성 장애 아동 집단은 (1) 서울, 경기 지역에 거주하며, (2) 소아정신과 또는 신경정신과에서 DSM-5의 진단기준에 입각하 여 자폐범주성장애로 진단받고, (3) KABC-II (Korean Kaufman Assessment Battery for Children, 2nd edition; Moon, 2014)의 비언 어성 검사(손동작, 삼각형, 시각유추, 위치기억, 사진순서) 결과 동 작성 지능 점수가 70점 이상이며, (4) 부모 보고에 의해 시각 및 청 각 등의 감각 장애를 보이지 않는 아동 12 명을 선정하였다. 일반 아 동 집단은 고기능자폐성 장애 아동 집단과 언어 및 생활연령을 일 치시킨 집단으로, 부모나 교사에 의해 언어능력이나 지적능력이 정 상이라고 보고되고, 고기능자폐성 장애 아동 집단과 (1), (3), (4)번 항목이 동일한 조건에 있는 아동 12 명을 선정하였다.

본 연구에 참여한 고기능자폐 아동 집단의 평균 생활연령은 7세 0 개월 $(\mathrm{SD}=17.68$, 수용 어휘력 평균은 $74.50(\mathrm{SD}=11.67)$ 점, 표현 어 휘력 평균은 $76.75(\mathrm{SD}=9.55)$ 점, 동작성 지능지수 평균은 108.00 $(\mathrm{SD}=12.64)$ 점이었다. 일반 아동 집단의 평균 생활연령은 6세 11 개 월( $\mathrm{SD}=17.01)$, 수용 어휘력 평균은 $79.33(\mathrm{SD}=14.09)$ 점, 표현 어휘 력 평균은 $83.25(\mathrm{SD}=13.02)$ 점, 동작성 지능 지수의 평균은 120.41 $(\mathrm{SD}=7.64)$ 점이었다. 두 집단은 생활연령 $(t=-.106, p>.05)$ 을 비롯 하여, 수용 어휘력 $(t=.915, p>.05)$ 과 표현 어휘력 $(t=1.394, p>.05)$, 그리고 $\mathrm{KABC}-\mathrm{II}$ 동작성 점수 $(t=2.910, p>.05)$ 에서도 통계적으로 유의한 차이를 보이지 않았다. 각 집단별 자세한 정보는 Table 1과 같다.

\section{연구도구}

\section{존대법 유형에 따른 의사소통 조율능력 과제}

본 연구에서는 화용 언어(Pragmatic language) 능력을 평가하기 위하여 '한국아동 메타-화용언어검사(Korean meta-Pragmatic Language Assessment for Children, KOPLAC; Kim, Song, Kim, \& $\mathrm{Kim}, 2018$ )'의 하위 과제인 '대화 상대자에 의한 의사소통 조율능 력'과제를 사용하였다. KOPLAC은 DSM-5와 화용언어에 대한 문 
Table 1. Participants' characteristics

\begin{tabular}{lcc}
\hline & HF-ASD (N=12) & TD (N=12) \\
\hline Age (mo) & $84.00(17.68)$ & $83.25(17.01)$ \\
REVT & & \\
$\quad$ Receptive & $74.50(11.67)$ & $79.33(14.09)$ \\
Expressive & $76.75(9.55)$ & $83.25(13.02)$ \\
KABC-II & $108.00(12.64)$ & $120.41(7.64)$ \\
\hline
\end{tabular}

Values are presented as mean (SD).

HF-ASD = high-functioning autism; TD = typically developing children; REVT= Receptive \& Expressive Vocabulary Test (Kim, Hong, Kim, Jang, \& Lee 2009); KABC-\| = Kaufman Assessment Battery for Children, 2nd edition (Moon, 2014).

헌연구를 토대로, 만 5 세에서 12 세 아동의 화용 언어 능력 평가를 목적으로 개발되었다. KOPLAC은 화용언어규칙에 대한 인식 능 력, 즉 메타-화용언어능력을 평가하기 위해 의사소통 조율능력과 담화 및 이야기 정보 추론 능력, 그리고 상위언어 인식 능력, 이렇게 3 개의 하위 검사로 구성되어 있다(Kim et al., 2018). KOPLAC은 노 트북에 탑재하여 아동에게 제공하는 시청각적 담화과제로, 아동 은 문항 별 대화 상황을 묘사한 그림을 보면서, 사전에 녹음된 대화 내용을 들으며 진행된다.

본 과제는 존대법 유형에 따른 의사소통 조율능력을 알아보기 위하여 대화 상대자에 따라 어휘 및 문법형태소를 적절히 사용하 는 존대 및 하대 규칙을 인식하고 수정하는 능력을 평가한다. 과제 는 연습 문항 1 개와 하대조율 10 문항, 존대조율 10 문항, 그리고 위 문항(false-item) 2 개, 총 23개 문항으로 구성되었다. 존대 및 하대 과제는 어휘와 문법형태소에 따른 조율로 다시 나뉘며, 각각 어휘 조율 5문항, 문법형태소 조율 5문항으로 구성하였다. 연습 문항은 적절한 대화와 부적절한 대화를 하나씩 제시하였고, 위 문항을 제 외한 본 과제는 모두 대화 상대자에 따라 존대법 사용이 부적절한 경우이다. 아동은 문항을 듣고 적절성 여부를 판단하며, 부적절하 다는 것을 인식했을 때는 아동에게 적절한 표현으로 수정하도록 요구하였다. 문항의 예시는 Appendix 1에 제시하였다.

문항에 사용한 조율은 Sung (2007)의 분류체계를 참고하여 구 성하였고, 각 상황에 사용된 어휘와 문법형태소는 Table 2와 같다.

\section{연구절차}

본 연구는 대학 소속 언어병리학과 임상 실습실에서 진행하였다. 모든 검사는 아동과 검사자가 1 대 1 로 이루어졌고, 평가 과제는 총 2 회기 나눠 실시하였다. 먼저 참여 아동 선별을 위해 KABC-II (Moon, 2014)의 동작성 검사와 수용 - 표현어휘력검사(REVT; Kim, Hong, Kim, Jang, \& Lee, 2009)를 실시하고, 그 결과 동작성 지능이 70점 이상인 아동에 한하여 2 회기에 의사소통 조율 과제를 실시하였다.
Table 2. Honorific vocabularies and grammatical morphemes

\begin{tabular}{|c|c|}
\hline Situation & Category \\
\hline \multicolumn{2}{|c|}{ Honorific items (dialogue with older person) } \\
\hline \multicolumn{2}{|c|}{$\begin{array}{l}\text { Grammatical morphemes -ka/kkeyse, -i/kkeyse, -hanthey/kkey, -eykey/kkey, -(u)si } \\
\begin{array}{l}\text { Vocabularies } \\
\text { issta/kyeysita, aphuta/phyenchannusita, pap/cinci, } \\
\text { pota/poypta, na/ce }\end{array}\end{array}$} \\
\hline \multicolumn{2}{|c|}{ Non-honorific items (dialogue with peer or younger person) } \\
\hline \multicolumn{2}{|c|}{$\begin{array}{l}\text { Grammatical morphemes -i/kkeyse, -hanthey/kkey, -eykey/kkey, -(u)si-, -ta, } \\
\begin{array}{l}\text { Vocabularies } \\
\text {-al-el/-(a/e)/yo } \\
\text { mal/malssum, nai/yensey, teylita/mosita, mutta/ } \\
\text { yeccwupta, ya/yorobun }\end{array}\end{array}$} \\
\hline
\end{tabular}

Table 3. Scoring criteria

\begin{tabular}{ll}
\hline Score & Criteria \\
\hline 0 & $\begin{array}{c}\text { Fail to recognize situations in which honorific expressions are used } \\
\text { incorrectly }\end{array}$ \\
1 & $\begin{array}{l}\text { Recognize the situations, but cannot correct the incorrect honorific } \\
\text { expressions }\end{array}$ \\
2 & $\begin{array}{l}\text { Recognize the situations, and correct the incorrect honorific } \\
\text { expressions }\end{array}$ \\
\hline
\end{tabular}

\section{신뢰도}

신뢰도 평가는 전체 아동 자료 중 $20 \%$ 에 해당하는 5 명의 자료를 무작위로 선택한 후, 연구자와 신뢰도 평가자의 분석결과 간의 일 치율을 구하여 산출하였다. 신뢰도 평가자는 연구의 내용을 잘 알 고 있는 언어병리학 석사 1 명이 연구의 내용 및 채점기준을 충분히 숙지한 후, 신뢰도 평가를 실시하였다. 신뢰도는 평가자 간의 평가 결과를 비교하고 일치도를 계산하였다. 즉, 일치한 항목 수를 일치 한 항목 수와 불일치한 항목 수의 합으로 나눈 후에 100 을 곱하여 신뢰도를 산출한 결과 대화상대자에 따른 존대법 조율능력 과제 정확도에 대한 평가자간 신뢰도는 $100 \%$ 로 나타났다.

\section{자료분석}

본 과제는 연습 문항 1 문항과 위 문항 2 문항, 존대법 조율능력 문 항 20 문항으로 총 23 문항이다. 각 문항당 총점은 2점으로 연습 문 항과 위 문항은 채점에서 제외하였고, 조율능력 20 문항의 총점은 40점이다. 채점 기준은 Table 3과 같으며, 집단 간 수행력 차이를 살 펴보기 위해 일원혼합분산분석(One-way ANOVA)을 실시하고, 어휘 및 문법형태소에 따른 존대법의 수행 수준은 이원혼합분석 (Two-way ANOVA)를 실시하였다. 모든 자료는 SPSS/WIN 25.0을 사용하여 분석하였다.

총점 이외에도 집단 간 오류 유형 분석을 실시하였다. 오류 유형 은 존대법이 잘못 사용된 상황을 인식하지 못하는 '인식 오류'와 인 
식은 적절히 했으나 어법에 맞게 수정하지 못한 ‘수정 오류’로 나누 었다. 수정오류는 다시 문법형태소를 생략하거나 잘못 사용한 '형 태 오류', 어휘를 잘못 사용하거나 생략한 '의미 오류', 상황맥락과 관련 없는 말로 바꾸어 말한 ‘화용 오류’로 분류하였다. 오류 분석 은 각 집단 별 오류 유형의 빈도와 백분율(\%)로 환산하였다.

\section{연구결과}

\section{존대-하대 유형에 따른 의사소통 조율능력 비교}

집단 간 존대법 조율능력 과제에서 존대-하대에 따른 수행점수 를 분석한 결과, 고기능자폐 집단은 하대에서 평균 4점, 존대에서 평균 4.83 점의 수행을 보였다. 이에 비해 일반 아동 집단은 하대 평 균 11.75점, 존대 평균 7.08점으로 고기능자폐 집단에 비해 높은 수 준을 나타냈다. 집단 간 수행 차이를 알아보기 위하여 일원혼합분산 분석 결과, 그룹 간 주효과가 통계적으로 유의하였다 $\left(F_{(1,22)}=18.299\right.$, $p<.001$ ) (Table 4, Figure 1).

또한 존대와 하대에 따른 그룹 간 상호작용 효과가 통계적으로 유의 하였다 $\left(F_{(1,22)}=9.974, p<.05\right)$. 고기능자폐 아동의 경우 하대에 서의 수행에 비해 존대에서의 수행이 상대적으로 높았으나, 일반 아 동은 하대에서 수행이 높고 존대에서의 수행이 상대적으로 낮게 나 타났다. 즉, 하대 조율 점수에서 일반아동 집단과 고기능자폐 아동 집단의 수행능력 차이가 존대 조율 점수에서 일반 아동 집단과 고

Table 4. Results of one-way ANOVA by group

\begin{tabular}{lcccc}
\hline Group & Non-honorifics & Honorifics & $F_{1,22)}$ & $p$ \\
\hline HF-ASD (N=12) & $4.00(3.07)$ & $4.83(2.58)$ & 18.299 & .000 \\
TD (N=12) & $11.75(4.48)$ & $7.08(3.36)$ & & \\
\hline
\end{tabular}

Values are presented as mean (SD).

HF-ASD = high-functioning autism spectrum disorder; $T D$ = typically developing children.

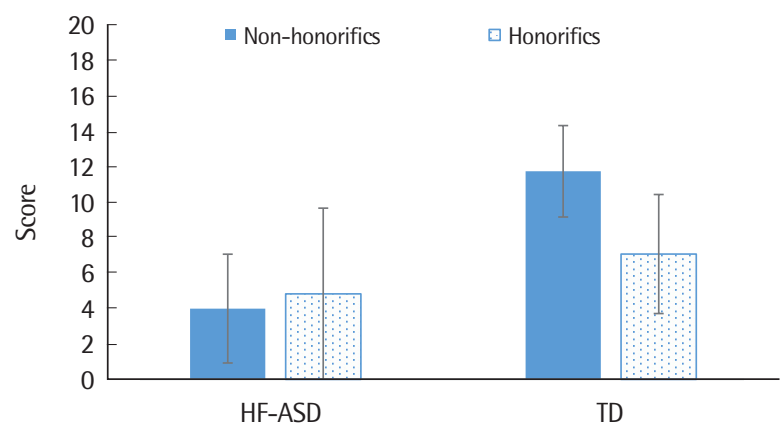

Figure 1. Honorific and non-honorific scores of HF-ASD and TD. HF-ASD = high-functioning autism spectrum disorder; TD = typically developing children.
기능자폐 아동 집단의 수행능력 차이보다 유의하게 컸다(Figure 2).

\section{어휘와 문법형태소에 따른 의사소통 조율능력 비교}

고기능자폐 아동 집단과 일반 아동 집단의 존대법 어휘와 형태 소 조율에 따른 집단 간 수행능력을 비교한 결과, 그룹 간차이가 통

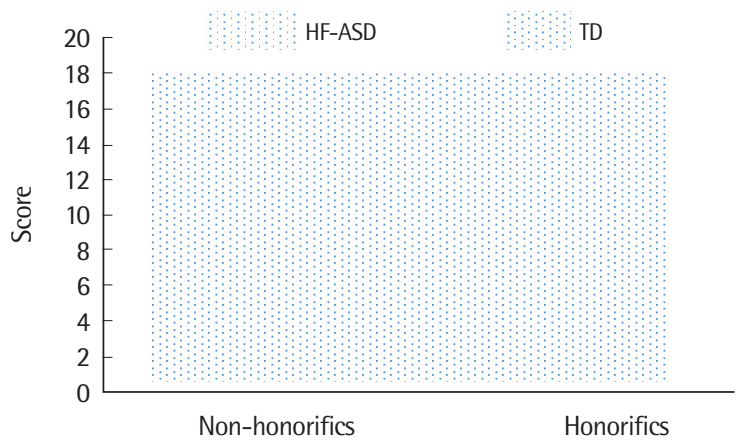

Figure 2. Task type (non-honorifics vs. honorifics) and group interaction graph. HF-ASD = high-functioning autism spectrum disorder; TD = typically developing children.

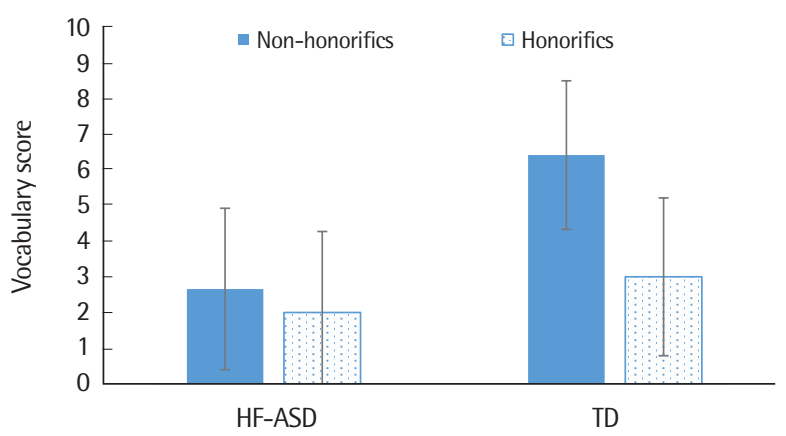

Figure 3. Vocabulary scores of HF-ASD and TD.

HF-ASD = high-functioning autism spectrum disorder; TD = typically developing children.

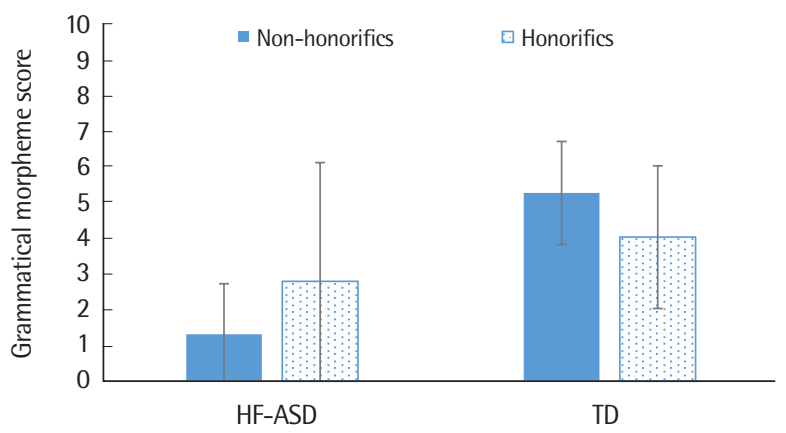

Figure 4. Grammatical Morpheme scores of HF-ASD and TD. HF-ASD = high-functioning autism spectrum disorder; TD = typically developing children. 

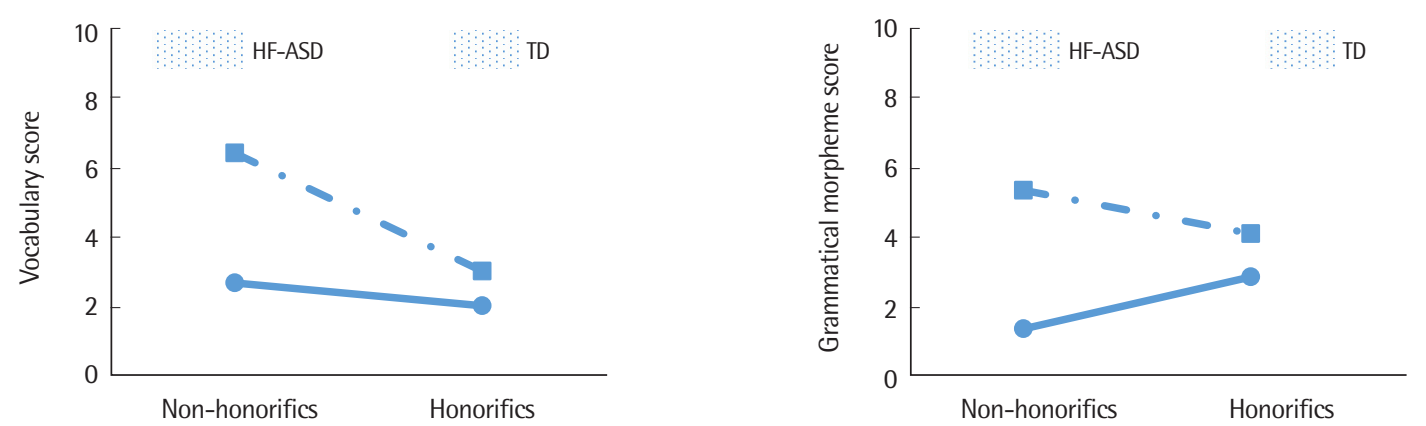

Figure 5. Task type (non-honorifics vs. honorifics) and group interaction graph of vocabulary and grammatical morpheme scores. HF-ASD= high-functioning autism spectrum disorder; TD= typically developing children.

Table 5. Error frequency by error type

\begin{tabular}{lcc}
\hline Error type & HF-ASD (N=12) & TD (N=12) \\
\hline Recognition & $14.25(80)$ & $9.75(84.7)$ \\
Correction & & \\
Morphology & $1.42(8)$ & $1(8.8)$ \\
Vocabulary & $0.92(5)$ & $0.67(5.8)$ \\
Pragmatic & $1.33(7)$ & $0.08(0.7)$ \\
Subtotal & $3.67(20)$ & $1.75(15.3)$ \\
Total & $17.92(100)$ & $11.5(100)$ \\
\hline
\end{tabular}

Values are presented as mean of error frequency (percentage). HF-ASD = high-functioning autism spectrum disorder; TD=typically developing children.

계적으로 유의하였다 $\left(F_{(1,22)}=18.299, p<.05\right)$. 즉, 어휘 및 형태소 조 율 모두에서 일반아동의 평균 수행 점수가 고기능자폐 아동의 평 균수행 점수보다 유의하게 높게 나타났다(Figures 3,4).

존대법 어휘와 문법형태소에 따른 집단 간 상호작용 효과는 유의 하지 않았다 $\left(F_{(1,22)}=.107, p>.05\right)$. 존대법 어휘 점수는 하대 어휘에서 고기능자폐 아동의 평균 수행이 2.66점, 일반아동의 평균이 6.41점 으로, 월등히 차이가 컸으나, 존대 어휘에서는 고기능자폐 아동의 평 균은 2.00점, 일반 아동의 평균은 3.00점으로 그 차이가 작았고, 이 는 통계적으로 유의하지 않았다. 존대법 형태소 점수는 하대 형태소 에서 고기능자폐 아동의 평균 1.33 점, 일반 아동의 평균 5.33 점으로 그차이가 컸고, 존대 형태소에서 고기능자폐 아동의 평균 2.83 점, 일 반 아동의 평균 4.08 점으로 그 차이가 작았으나, 이 또한 통계적으로 도 유의하지 않았다. 존대법 어휘 능력에서 고기능자폐 아동과 일반 아동 모두 하대에서 수행 점수가 높았고, 존대에서 수행 점수가 낮았 다. 이에 비해존대법 문법형태소 점수는 존대-하대의 총점 분석에서 와 마찬가지로, 일반 아동이 하대에서 더 높은 점수를 보인 것에 비 해 고기능자폐 아동은 존대에서 더 높은 점수를 나타내, 그 양상이 달랐으나 통계적으로 유의한 결과는 아니었다(Figure 5).

\section{존대법 유형에 따른 의사소통 조율능력의 오류 비교}

본 연구에서는 고기능자폐 아동과 일반 아동에게 존대법의 오 류를 인식하는지 확인하고, 오류를 인식한 경우에는 오류를 수정 할 것을 요청하였다. 그 결과 각 아동이 보인 오류 유형을 인식 오류 와 수정 오류로 나누고, 수정 오류를 형태 오류, 의미 오류, 화용 오 류로 분류하였다(Table 5). 그 결과, 오반응 전체 빈도는 고기능자폐 아동 17.92 개, 일반 아동 집단 11.5 개였고, 두 집단 모두 수정 오류에 비해 인식 오류의 빈도가 높았다. 고기능자폐 아동 집단의 경우에 는 인식 오류 다음으로, 형태 오류, 화용 오류, 의미 오류 순으로 나 타난 것에 비해, 일반 아동 집단은 인식 오류 다음으로 형태 오류, 의미 오류, 화용 오류 순으로 나타났다.

\section{논의 및 결론}

본 연구는 고기능자폐 아동과 일반 아동을 대상으로, 존대법 유 형에 따라 의사소통 조율능력이 어떤지 알아보았다. 존대법은 크게 존대 및 하대로 나누고, 각각은 다시 어휘 및 문법형태소에 따른 유 형으로 나누어 그 수행 능력을 살펴보았다. 그리고 수행 결과에 따 라그 오류가 어떠한지 분석하였다.

\section{존대-하대에 따른 의사소통 조율능력}

먼저 존대-하대 유형에 따른 의사소통 조율능력에서 고기능자 폐 아동 집단은 일반 아동 집단에 비해 유의하게 낮은 수행력을 나 타내었으며, 또한 하대 조율 수행 점수에서 일반 아동과 고기능자 폐 아동 집단의 수행력 차이가 존대 조율 수행 점수에서 일반 아동 과 고기능자폐 아동 집단의 수행력 차이보다 유의하게 컸다. 이는 고기능자폐 아동이 일반 아동 집단에 비해 대화 상대자를 인식하 고 수정하는 조율능력에 어려움이 있음을 시사하며, Simmons 등 (2014)과 Lee 등(2007)의 연구결과에서 나타난 바와 같이, 대화능 
력에서 필요한 전제능력에 있어서 자폐 아동의 결함이 있다는 선행 연구결과와 일치한다. 즉 고기능자폐 아동들은 일반 아동들에 비 해 대화 상황에서 관여하는 여러 요인들을 파악하기 어렵고, 그 전 제가 되는 정보들을 파악하여 자신의 말을 적절히 조율할 수 있는 능력에 어려움을 보인다고 할 수 있다. 본 연구에서는 대화의 전제 정보로 대화 상대자를 요인으로 삼았고, 고기능자폐 아동은 실제 대화에서 대화 상대자, 즉 청자 요인에 따라 존대법 적용이 달라진 다는 것을 인식하는 데 취약함을 나타냈다. Han (2002)에 따르면 존대법이 실현될 때에는 사회 맥락적인 요인, 즉 청자와 화자 간의 관계에 있어서 나이와 사회적 지위, 공식성은 존대법이 잘 실현되 는데, 고기능자폐 아동은 대화 상황에서 청자와 화자의 관계에 따 라 존대법이 실현되는 언어 사용역 변이, 즉 의사소통 조율이 일어 난다는 것에 대해 어려움을 보이는 것이다. 한 가지 주목할 점은 일 반 아동 집단은 존대에 비해 하대 조율에서 더 높은 점수가 나타났 으나 고기능자폐 아동은 이와 반대의 결과를 보였고, 두 그룹 간 하 대 조율에서의 수행 차이와 존대 조율에서의 수행 차이는 유의한 상호작용을 나타냈다. 검사 중 한 일반 아동은 동생에게 존대를 사 용한 문항에 대해 ‘왜 동생한테 -께서 라고 그래요?’와 같이 청자보 다 나이가 어리고 친숙한 대상에게 존대법을 사용하는 것은 부적 절한 것이라고 인식하고 있었다. 이에 비해 고기능자폐 아동의 경 우 하대 상황에 대한 오류가 상대적으로 높게 나타났는데, 존대법 에 대한 문법적 지식을 갖고 있는 것과는 별개로, 화용적 측면에서 대화 상대자에 따른 존대법 적용은 취약하다는 것을 의미한다. 존 대 상황을 인식한다는 것은 하대 상황에 대한 지식이 있을 가능성 을 내포한다고도 볼 수 있는데 고기능자폐 아동에게서 유독 하대 상황의 오류가 유의하게 나타난다는 것은 이들이 또래와의 교류 가능이 낮다는 것을 반영한다고 할 수 있겠다.

\section{어휘와 문법형태소에 따른 의사소통 조율능력}

어휘와 문법형태소에 따른 의사소통 조율능력을 분석한 결과, 고기능자폐 아동 집단은 일반 아동 집단에 비해 유의하게 낮은 수 행능력을 나타냈다. 그러나 과제 유형과 집단 간 상호작용은 나타 나지 않았다. 고기능자폐 아동 집단은 어휘 존대법에서 또래에 비 해 유의한 차이를 보였지만, 그 양상은 유사하게 나타났다(Figure 5). 초등학교 3 학년이 되면 존대어휘의 $60 \%$ 이상을 습득하고 사용 한다는 연구결과(Kim, 2005; Lee, 2004; Won, 2003)와마찬가지로, 일반 아동에게도 존대 어휘 사용은 여전히 발달 중인 것으로 보이 며, 존대 어휘에 있어서는 고기능자폐 아동 집단에서도 일반 아동 집단과 유사한 양상을 보였다. 이에 비해 존대 문법형태소에 있어서 는 그 양상이 달랐다. 문법형태소로 실현되는 존대-하대에서 고기
능자폐 아동 집단은 수행도 유의하게 낮았지만, 그 양상도 일반 아 동 집단과 달랐다. 즉 고기능자폐 아동은 일반 아동과 달리 존대에 서의 수행이 상대적으로 높았는데, 이는 결국 문법형태소로 실현되 는 존대 능력이 상대적으로 우수하다는 점에서 이들의 형식언어 능력이 상대적으로 덜 손상된다는 선행연구와 일치한다고 볼 수 있 다(Kelly et al., 2006; Rapin \& Allen, 1983). 우리 말의 하대 표현에 서는 문법형태소의 복잡성이 덜하다. 특히 어미 사용에서 이와 같 은 특성은 두드러진다. 따라서 문법형태소를 통해 존대 표현이 상 대적으로 우수하다는 것은, 이와 같은 존대 표현에 필요한 복잡한 문법적인 능력을 이미 보유하고 있다는 것을 의미한다고 할 수 있 다. 그럼에도 불구하고 문법적으로 더욱 쉬운 형식인 하대에서의 수행이 떨어진다는 것은 고기능자폐의 의사소통 특성과 연관이 있 어 보인다. 즉 이들은 진단적 특성에 따라 또래와의 사회적 의사소 통에 어려움이 있고, 이에 따라 또래와의 교류가 적은 반면, 양육자 를 비롯하여 치료사나 교사처럼 지원자 역할을 하는 성인과의 교 류가 더 많다는 것이 일반적으로 알려진 바이다. 본 연구결과에는 우리말의 존대법 특성과 고기능자폐 아동의 진단적 특성뿐 아니라 의사소통 환경까지 반영된 것이라 할 수 있겠다.

\section{존대법 유형에 따른 의사소통 조율능력의 오류}

오류 유형 분석 결과 일반 아동 집단에 비해 고기능자폐 아동 집 단에서 전체 오류 빈도가 높게 나타났으며, 두 집단 모두 존대법이 잘못 사용된 상황을 인식하지 못하는 '인식 오류'의 출현이 가장 높 았다. 일반 아동은 ‘의미 오류'와 ‘화용 오류'에서 1 회 미만의 출현 률을 나타낸 반면, 고기능자폐 아동들은 '의미 오류'와 ‘화용 오류' 에서 각각 $5 \%$ 와 $7 \%$ 의 출현율을 나타내 오류유형에 차이가 있었다. 즉, 고기능자폐 아동들이 나타낸 오류 유형 중에서도 인식 오류가 가장 많다는 점은 대화 상황에서 나타나는 여러 요인들을 파악하 는 것에서부터 결함이 있다는 점을 말해준다. 또한 집단 간 오류 유 형에 차이가 나타난 것은 선행연구(Simmons et al., 2014)에서 언급 한 바와 같이 이들의 화용론적 결함에 기인한 것으로 보인다. 특히 고기능자폐 아동들은 존대법이 잘못 사용된 상황을 인식은 하지 만 그것을 수정하는 능력에 있어서 잘못된 상황맥락을 인식하는 것으로 보인다. 예를 들어 전화 상황에서 아이가 할머니께 존대법 을 잘못 사용한 경우(“할머니, 버스가 아직 안 도착하셨어요?”)에 한 자폐 아동은 ‘목소리가 이상해요’라고 대답하였다. 또한 옆집 친 구가 핸드폰을 놓고 간 상황에서 엄마가 아이에게 존대법을 잘 못 사용한 경우(“어머, 옆집 친구께서 핸드폰을 놓고 갔네.”)에 ‘안돼, 너 엄마 핸드폰 꺼에요.'라고 대답하는 등의 모습을 보였다. 이와 같 은 오류 반응을 볼 때에 자폐 아동은 지시문과 청자-화자와의 관 
계, 상황 등을 전체적으로 고려하기 보다는 대화 상황에서 나타나 는 여러 변인들 중에 특정 변인에만 집중하여 반응하는 양상이 관 찰되었다. $\mathrm{AAC}$ 사용자의 오류에 관한 연구에 의하면, $\mathrm{AAC}$ 사용자 의 오류 중, 화용적 오류로 분류한 ‘존대 오류'에서 상대방의 선호 도가 가장 낮게 나타났다. 즉, 말하는 사람이 나타내는 화용 오류 중에서도 존대 오류는 대화 상대자로 하여금 부정적인 평가를 불 러일으키며, 자폐 아동은 이러한 화용론적 결함으로 인해 다양한 사회적 관계에서 많은 어려움이 예상될 것으로 보인다.

고기능자폐 아동들은 어휘 및 문법에서 상대적인 강점을 보인다 는 지금까지의 연구결과와 달리, 존대법에 필요한 어휘 및 문법형태 소를 대화 상황에서 청자에 맞게 조율하는 능력에는 취약함을 보 였다. 따라서 본 연구의 결과를 통해, 고기능자폐 아동의 의사소통 조율능력을 촉진시키기 위해 존대법의 지도가 필요하며, 대화 상 대자에 따라 존대하는 상황과 하대하는 상황을 인식하는 것이 선 행되어야함을 시사하는 바이다.

본 연구는 고기능자폐 아동의 존대법 유형에 따른 의사소통 조 율능력을 실제 사용의 측면에서가 아니라, 사용된 것에 대해 메타화용언어 측면에서 살펴보았다. 이를 보완하기 위해, 직접적인 대화 상황에서의 존대법 사용이 어떠한지를 살펴보는 것이 필요하겠다. 또한 과제 문항을 개발하는 데 있어, 존대법의 사용 빈도를 반영하 고, 대화 상대자 요인을 구별하여, 그 결과 고기능자폐 아동은 어떤 양상을 보이는지에 대한 후속연구가 필요하다.

\section{REFERENCES}

Boucher, J. (2011). The autistic spectrum: characteristics, causes and practical issues. London: Sage.

Choi, J., \& Lee, Y. (2015). Contingency and informativeness of topic maintenance in children with high-functioning autism spectrum disorders. Communication Sciences \& Disorders, 20(3), 413-423.

Choi, J., Oh, S. J., \& Lee, Y. (2015). Language characteristics of school-aged children with high-functioning ASD through the LSSC. Special Education Research, 14(2), 139-156.

Chuba, H., Paul, R., Miles, S., Klin, A., \& Volkmar, F. (2003). Assessing pragmatic skills in individuals with autism and related disorders. In Presentation at the National Convention of the American Speech-Language-Hearing Association, Chicago, IL.

Dunn, M., Gomes, H., \& Sebastian, M. J. (1996). Prototypicality of responses of autistic, language disordered, and normal children in a word fluency task. Child Neuropsychology, 2(2), 99-108.
Han, K. (2002). A Study of Modern Korean Honorifics. Seoul: Youkrack.

Kelley, E., Paul, J. J., Fein, D., \& Naigles, L. R. (2006). Residual language deficits in optimal outcome children with a history of autism. Journal of Autism and Developmental Disorders, 36(6), 807-828.

Kim, K. E. (1991). A Comparative Study of Presupposition Ability between Normal and Mentally Retarded Children (Master's thesis). Ewha Womans University, Seoul, Korea.

Kim, S. K. (2005). A study on use and teaching of honorific system of elementary school students (Master's thesis). Chungbuk University, Cheongju, Korea.

Kim, Y. T., Song, S. H., J. A., \& Kim, H. C. (2018). Validity and reliability of Korean meta-pragmatic language assessment for children. Communication Sciences \& Disorders, 23(1), 94-108.

Kim, Y. T., Hong, G. H., Kim, K. H., Jang, H. S., \& Lee, J. Y. (2009). Receptive \& expressive vocabulary test (REVT). Seoul: Seoul Community Rehabilitation Center.

Klin, A., \& Volkmar, F. R. (2000). Treatment and intervention guidelines for individuals with Asperger syndrome. In A. Klin, F. K. Volkmar, \& S. S. Sparrow (Eds.), Asperger Syndrome (pp. 340-366). New York: The Guildfold Press.

Lee, E. M. (2004). A study on teaching methodology of honorific use expressions for elementary school students (Master's thesis). Chuncheon National University of Education, Chuncheon, Korea.

Lee, H. R., Kim, Y. T., \& Lee, S. B. (2007). Presuppositional skills in children with high functioning autism: given-new information processing. Communication Sciences \& Disorders, 12(2), 199-214.

Li. Z. Z. (2014). A contrastive study on honorific system between Korean and Chinese language (Master's thesis). Gachon University, Seongnam, Korea.

Ministry of Education. (2015a). 3-5 years old Nui-curriculum commentary. Seoul: Author.

Ministry of Education. (2015b). Elementary school education curriculum commentary. Seoul: Author.

Moon, S. B. (2014). Kaufman assessment battery for children, 2nd edition. Seoul: Hakjisa.

Mundy, P., \& Stella, J. (2000). Joint attention, social orienting, and nonverbal communication in autism. In A. M. Wetherby \& B. M. Prizant (Eds.), Communication and language intervention series; Vol. 9. autism spectrum disorders: a transactional developmental perspective (pp. 55-77). Paul H Brookes Publishing.

Oh, S. J., Lee, E. J., \& Kim, Y. T. (2012). Preliminary study on developing test 
items of children's pragmatic language checklist. Journal of Speech-Language \& Hearing Disorders, 21(2), 111-135.

Okamoto, S. (1999). Situated politeness: manipulating honorific and nonhonorific expressions in Japanese conversations. Pragmatics, 9(1), 51-74.

Park, J. L., \& Kim, M. J. (2010). A study to the acquisition of honorific markers by three-, four-, and five-year-old young children. Korean Journal of Child Studies, 31(6), 153-166.

Paul, R. (2007). Language disorders from infancy through adolescence: assessment \& intervention (3rd ed.). St/ Louis: Mosby Elsevier.

Rapin, I., \& Allen, D. (1983). Developmental language disorders: nosologic considerations. In U. Kirk (Ed.). Neuropsychology of language, reading, and spelling (pp. 155-184). New York: Academic Press.

Simmons, E. S., Paul, R., \& Volkmar, F. (2014). Assessing pragmatic language in autism spectrum disorder: the Yale in vivo pragmatic protocol. Journal of Speech, Language, and Hearing Research, 57(6), 2162-2173.

Sung, K. C. (2007). Korean Honorifics \& Korean Language Education. Seoul:
Geulnurim.

Volden, J., Magill-Evans, J., Goulden, K., \& Clarke, M. (2007). Varying language register according to listener needs in speakers with autism spectrum disorder. Journal of Autism and Developmental Disorders, 37(6), 1139-1154.

Volden, J., \& Sorenson, A. (2009). Bossy and nice requests: varying language register in speakers with autism spectrum disorder (ASD). Journal of Communication Disorders, 42(1), 58-73.

Wetherby, A. M., Prizant, B. M., \& Hutchinson, T. A. (1998). Communicative, social/affective, and symbolic profiles of young children with autism and pervasive developmental disorders. American Journal of Speech-Language Pathology, 7(2), 79-91.

Won, J. H. (2003). A Study on analyzing the usage of honorific expression and honorific education for elementary students-focus on third-, fourth-, fifth-, and sixth-grade elementary students (Master's thesis). Chungbuk University, Cheongju, Korea. 
Appendix 1. Examples of experimental task

존대법 조율
하대
형태소 조율(-한테/께)

어휘 조율(밥/진지)

오늘 지훈이와 친구들은 민수네 집에 놀러 가기로 했어요. 지훈이는 처음 가는 길이라 버스를 타야 하는지 지하 철을 타야 하는지 몰랐어요. "뭘 타고 가야 하지?" “글쎄, 우리 민수께 전화해 볼까?”

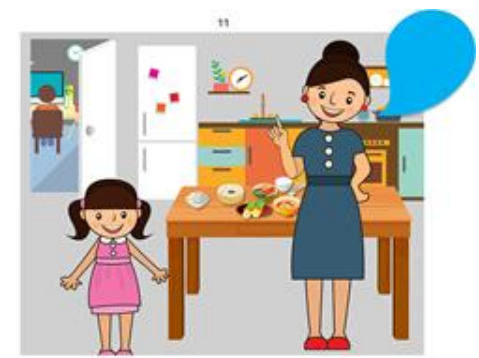

오늘은 집에 할머니, 할아버지께서 오셔서 다 같이 식사를 하게 되었어요. 그런데 오빠는 방에서 게임을 하고 있 었어요. "하영아 오빠한테 진지 먹게 나오라고 하렴."

존대

형태소 조율(-(으)시-)

어휘 조율(데리다/모시다)

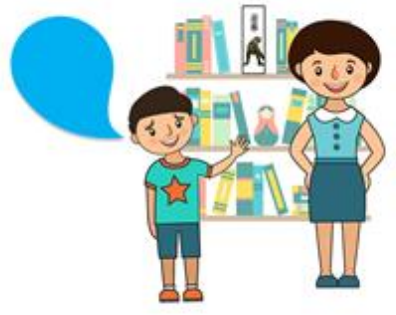

민수는 공룡이 나오는 책을 좋아해요. 그런데 공룡책이 맨 위에 꽃혀있어서 꺼낼 수가 없었어요. 그래서 선생님 께 공룡책을 꺼내달라고 부탁을 했어요. "선생님 책 좀 꺼내 줘."

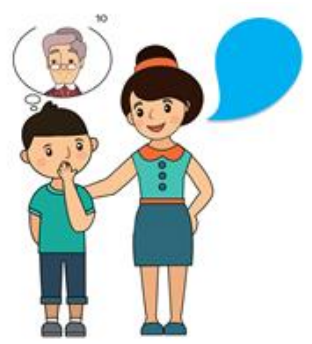

오늘은 할머니께서 집에 놀러 오시는 날이에요. 민수는 엄마와 할머니를 마중 가기로 했어요. "민수야 할머니 데 리러 가자" 


\title{
국문초록
}

\author{
일반아동과 고기능자폐아동의 존대법 유형에 따른 의사소통 조율능력 비교 \\ 이명희 ${ }^{1}$ 송승하 ${ }^{2} \cdot$ 김영태 $^{1}$ \\ ${ }^{1}$ 이화여자대학교 언어병리학과, ${ }^{2}$ 샘언어발달연구소
}

배경 및 목적: 고기능 자폐아동은 일반아동과 비슷한 수준의 언어적인 능력을 갖고 있으나, 청자나상황에 맞게 자신의 말을 적절히 조 절하는 화용론적 결함을 보인다. 한국어는 자신의 말을 맥락에 맞게 조율하는 표현의 하나로 존대법이 발달되어 있다. 본 연구는 고기 능 자폐아동가 대화상대자에 따라 존대법의 사용능력이 어떤지 알아보고자 하였다. 방법: 만 5 세에서 9 세 사이의 고기능 자폐아동 12 명과 일반아동 12 명, 총 24 명이 연구에 참여하였다. 대화 상대자에 따른 의사소통 조율 과제는 총 23 문항으로 구성되었고, 각 문항은 존 대 및 하대 상황의 대화로 제작하여, 존대법 사용에 필요한 어휘 및 형태소의 적절성을 판단하고, 부적절한 표현을 수정하는 능력을 살 펴보았다. 연구결과는 집단 간 수행 능력의 차이와 오류 유형 분석으로 고찰하였다. 결과: 대화 상대자에 따라 존대법 조율능력은 고기 능 자폐아동 집단이 일반아동에 비해 유의하게 낮았다. 또한 어휘 및 형태소 조율에서도 동일한 양상이 나타났다. 오류 유형에서는 두 집단 모두 수정오류에 비해 인식오류가 높게 나타났으나, 고기능 자폐아동에게서 그 빈도가 높았고, 오류 유형은 형태오류, 화용오류, 의미오류의 순으로 높게 나타났다. 논의 및 결론: 고기능 자폐아동은 대화상대자에 따라 존대법을 사용하는 상황을 인식하고, 수정하 는 능력에서 또래에 비해 유의한 어려움을 보였다. 일반아동과 달리, 고기능 자폐아동은 하대에서 보다 취약하였으며, 이는 또래와의 교 류가 적은 것을 반영하는 것이라 할 수 있다. 따라서 고기능 자폐아동에게 존대법의 지도가 필요하며, 중재 시 존대법을 적용하는 상황 에 대한 인식이 선행되어야 하겠다.

핵심어: 의사소통 조율능력, 존대법, 화용언어, 고기능 자폐범주성장애

본연구는 2018년 대한민국 교육부와 한국연구재단의 지원을 받아 수행된 연구임(No. NRF-2018S1A3A2075274).

\section{참고문헌}

교육부(2015a). 3-5세 누리과정 해설집. 서울: 교육부.

교육부(2015b). 초등 교육과정 해설집. 서울: 교육부.

김경은(1991). 정신지체아동과 정상아동의 청자특성에 따른 전제(前提, Presupposition)능력에 관한 비교 연구. 이화여자대학교 석사학위논문. 김세경(2005). 초등학생의 높임법 사용 실태와 분석을 통한 지도 방안 연구. 충북대학교 교육대학원 석사학위논문.

김영태, 송승하, 김정아, 김효창(2018). 한국아동 메타-화용언어검사(KOPLAC)의 개발: 타당도와 신뢰도. Communication Sciences \& Disorders, 23(1), 94-108.

김영태, 홍경훈, 김경희, 장혜성, 이주연(2009). 수용· 표현어휘력검사(Receptive \& Expressive Vocabulary Test, REVT). 서울: 서울장애인종합복지관. 문수백(2014). 카우프만 아동용 지능검사 II (Kaufman Assessment Battery for Children, 2nd edition). 서울: 학지사.

박진이, 김민진(2010). 만 3, 4, 5세 유아의 존댓말 습득에 관한 연구. 아동학회지, 31(6), 153-166.

성기철(2007). 한국어 대우법과 한국어 교육. 서울: 글누림.

오소정, 이은주, 김영태(2012). 화용능력 체크리스트 문항 개발을 위한 예비 연구. 언어치료연구, 21(2), 111-135.

원종희(2003). 초등학생의 높임법 사용 실태 분석과 지도 방안 연구:3.4.5 6학년을 중심으로. 한국교원대 교육대학원 석사학위논문.

이은미(2004). 초등학생의 대우법 사용 지도 방법 연구. 춘천대학교 교육대학원 석사학위논문.

이진진(2014). 한·중 존대법의 대조연구. 가천대학교 대학원 석사학위논문.

이희란, 김영태, 이승복(2007). 고기능 자폐아동의 주어진 정보와 새로운 정보 처리능력. 언어청각장애연구, 12(2), 199-214.

최지은, 오소정, 이윤경(2015). 학령기 고기능 자폐범주성장애 아동의 언어특성. 특수교육, 14(2), 139-156. 
최지은, 이윤경(2015). 학령기 고기능 자폐스펙트럼장애 아동의 주제유지능력. Communication Sciences \& Disorders, 20(3), 413-423.

한길(2002). 현대 우리 말의 높임법 연구. 역락.

\section{ORCID}

이명희(제1저자, 대학원생 https://orcid.org/0000-0002-7535-4538); 송승하(공동저자, 언어재활사 https://0000-0003-4537-7728); 김영태(교신저자, 교수 https://orcid.org/0000-0003-1738-6862) 